\title{
Commissive Speech ACt In The Movie John WiCk Chapter 2
}

\author{
I Wayan Juniartha, Desak Putu Eka Pratiwi, I Made Yogi Wijaya \\ Mahasaraswati Denpasar University, Bali \\ r_juniartha@yahoo.com, desak.eka.pratiwi@gmail.com, yogiwijaya045@gmail.com
}

\begin{abstract}
Commisive is a kind of speech acts that used by the speakers to commit themselves to some future course action. It expresses the speaker's attention to do something on some future action. This study concerned on finding out the types of commissive speech act used by characters in the movie John Wick Chapter 2, as well as analyzing the meaning of its utterances. This study applied the theory of pragmatics from Yule (1996) to find out the types of commissive speech act, theory of meaning from Thomas (1995) to analyse the implied meaning and supported by the theory of context of situation from Halliday and Hasan (1989). The data were collected by observation method and analysed by descriptive qualitative method. The finding is presented in formal and informal way. Our finding shows that there are four types of commisive speech acts which predominantly used by the characters in the movie John Wick Chapter 2, they are: refusal $(12 \%)$, warning $(48 \%)$, promise $(12 \%)$ and threat $(28 \%)$.
\end{abstract}

Keywords: commissive, speech act, utterance, meaning

\section{INTRODUCTION}

In a communication, people deliver their thoughts and ideas through speeches in many different ways. However, some issues happened in communication due to misunderstanding between the speaker and the hearer. Therefore, it is important to know the implied meaning of the utterances in a communication by understanding the topic and context of situation. Pragmatics is the study which belief that what is communicated is more than what is said. It means pragmatics is closely related to the analysis of what people mean by their utterances than what the words or phrases in those utterances might mean by themselves (Yule, 1996: 3). Here what Yule want to emphasize is the meaning that speakers have is more than the words they say.

To understand the meaning of the utterances spoken by the speaker, we might also pay attention to the context. Thus, pragmatics also concerns with context. Pragmatics should also consider aspects of context such as who people are talking to, when, where, and under what circumstances that will determine the way they say and what they want to say. We cannot simply judge the meaning through what people say. In many ways, pragmatics is the study of invisible meaning, and how we recognize, what is meant even it is not actually said or written. In order for that to happen the speaker or writer must be able to depend on a lot of shared assumption and expectation. Pragmatics concerns to people's assumption, people purposes, and the types of action that they are performing when they speak (Yule, 1996: 4).

When we produce utterances, we do not simply make statements or say something without any intention. Yule (1996: 47) states that speech acts is action, which is performed via utterances. Here people can perform an action by saying something. The speakers do not need to do the action physically. The utterances said would be sufficient to perform an action. We perform speech act when we offer an apology, greeting, request, complaint, invitation, compliment, or refusal. In particular, this study focussed on commisive speech act.

Commisive is kind of speech acts that used by the speakers to commit themselves to some future course action. They express the speaker's attention to do something on some future action. Sometimes, someone wants to do something in the future times by saying something such as promise, threat, warning, or refusal. It can be performed alone by the speaker, or by the speaker as the member of the group. In using commissive, the speaker undertakes the world to fit the words (Yule, 1996: 54). These words that people deliver during the conversation in movie, speech, or daily conversation is not as simple as it seen. They have their implied meaning that makes it very interesting to be analysed. This study aims at identifying types of commissive speech act and the implied meaning of the utterances as delivered by the characters in the movie John Wick Chapter 2 .

\section{MATERIALS AND METHOD}

The data of this study were taken from the movie John Wick Chapter 2. The data were taken from the utterances of selected characters in the movie, they are: John Wick, Winston, Santino D'Antonio, Giana D'Antonio, Bowery King, Cassian, Abram, and Julius. The data were collected through 
observation method by watching the movie repeatedly. The data were classified into types of commissive speech act such as: refusal, warning, promise and threat. The data then analyzed qualitatively by using some theories, such as theory of pragmatics from Yule (1996) to identify types of commissive speech act; theory from Thomas (1995) to analyse the meaning of the utterances; and supporting theory from Halliday and Hasan (1989) to analyse context of situation. The data were presented in formal and informal method.

\section{RESULTS AND DISCUSSION}

Our finding shows that there are four types of commissive speech act that predominantly u sed by the characters in the movie John Wick Chapter 2, they are warning, threat, promise, and refu sal. It can be seen in the table below.

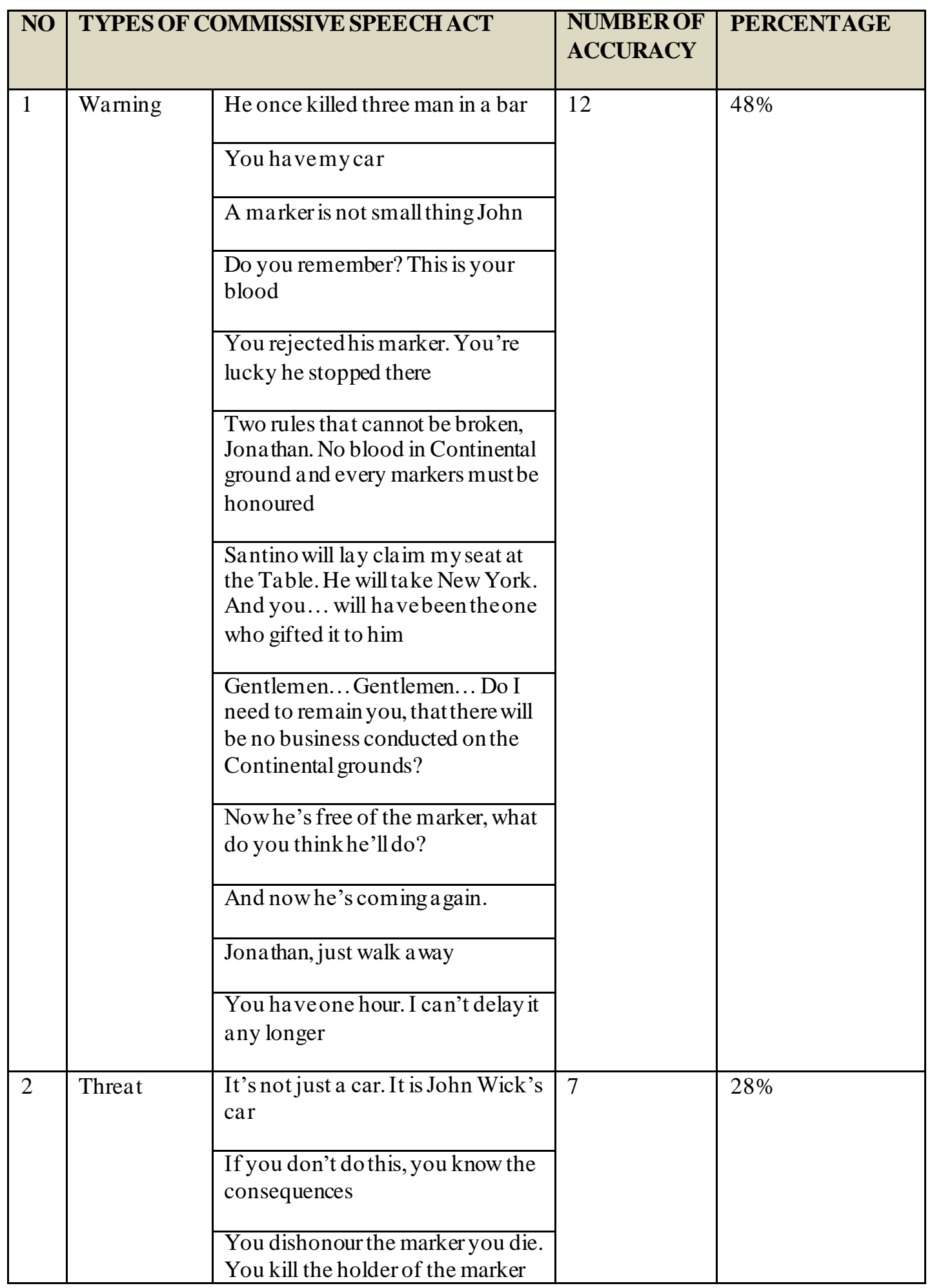




\begin{tabular}{|c|c|c|c|c|}
\hline & & you die. You run you die & & \\
\hline & & $\begin{array}{l}\text { An eye for an eye John. You Know } \\
\text { how it goes }\end{array}$ & & \\
\hline & & $\begin{array}{l}\text { You want a war? Or do you wanna } \\
\text { just give me a gun? }\end{array}$ & & \\
\hline & & $\begin{array}{l}\text { The door in any service or provider } \\
\text { in connection with the Continental } \\
\text { are now closed to you. I a m sorry. } \\
\text { Your life is now forfeit }\end{array}$ & & \\
\hline & & John Wick Excommunicado & & \\
\hline 3 & Promise & $\begin{array}{l}\text { All right. It will be ready } \\
\text { Christmas }\end{array}$ & 3 & $12 \%$ \\
\hline & & I promise & & \\
\hline & & I'll kill them. I'll kill them all & & \\
\hline 4 & Refusal & $\begin{array}{l}\text { No one gets out and comes back } \\
\text { without repercussion }\end{array}$ & 3 & $12 \%$ \\
\hline & & Find someone else & & \\
\hline & & I can't help you & & \\
\hline & Total & & 25 & $100 \%$ \\
\hline
\end{tabular}

All types of commisive speech acts are explained in the following section. Only ten selected examples are presented in the discussion.

\subsection{WARNING}

Warning is utterance that aims other to be careful. It could be an advice, a warn, a suggestion. In the movie John Wick Chapter 2, twelve utterances which categorized as warning are found. The selected examples are explained as follows:

Data 1

Abram : He once killed three men in a bar.

Abram's subordinate: With a pencil. I know. I've heard that story.

Abram : With the fuckin pencil. Who the fuck can do that?

(00:05:42-00:05:49)

The data above is a conversation between Abram and his subordinate. The conversation took place in Abram headquarter. Abram and his subordinate talked about how feared John Wick is by everyone and what he has done. Everyone who works at underworld crime knows the story about John Wick who killed three men in a bar just by using a pencil. Abram used declarative sentence to state a fact about John Wick. In this conversation he emphasized to his subordinate who John Wick actually is. Abram said, He once killed three men in a bar. The utterance can be categorized as warning since Abram warned his subordinate that John Wick killed three men in a bar just by using a pencil. Thus, the sentence means that if they wanted to face John Wick, it could be very hard to win over him. Abram said 
that to make his subordinate be careful and alert about possibilities that will happen if they messed with John Wick.

\section{Data 2}

John Wick: You have my car.

Abram : Baba Yaga

(00:06:25)

The conversation is between John Wick and Abram. They talked about John Wick's car which stolen by Abram's nephew and now it is in Abram headquarter. Abram headquarter is the place where Abram runs his crime. John Wick told Abram that he knew his car is there and he will take it back. Everyone knows there are three things that John Wick loves the most; they are his wife, his car, and his dog. If somebody dared to steal one of them, they must pay it back. The type of sentence that used by John Wick is declarative sentence, since John Wick declared something that based on the fact or truth.

This utterance is categorized into warning. John Wick warned Abram that he will take his car back no matter what. He warned Abram that there will be a danger or problem because Abram kept John Wick's car in his headquarter. John Wick will take an action when he says You have my car to Abram. Finally, John Wick killed Abram's nephew because he did not only steal his car but also killed his dog.

Data 3

SantinoD'Antonio: This is because of me. This, in part, is mine.

John Wick : Take it back.
Santino D'Antonio: Take it back?
John Wick : Take it back.

Santino D'Antonio: A marker is not small thing John.

(00:21:46-00:21:56)

The conversation is between John Wick and Santino, which took place in John Wick's house. They talked about a plan to kill Santino's sister. Santino's family has a right to stand in one of twelve seats on High Table as the Comorra or Italian Mafia. That position was held by Santino's father. After his father died, the position is replaced by his sister Giana D'Antonio. That is why he wants his sister die. No matter how hard Santino attempted to persuade John Wick, he kept refuse it. Then Santino showed John Wick the evidence of their engagement. There is John Wick blood on a kind of agreement paper. The blood shows the evidence that John Wick has a marker with Santino D'Antonio. If a hit man had a marker with someone, he will be paid to kill somebody. If he broke the marker, he will get a punishment. The High Table will find and kill him.

Santino's utterance is categorized into warning. Santino used declarative sentence, declaring how important that marker is. This kind of sentence is used to inform something true or based on the fact. On the other hand, John Wick refused Santino's demand to kill his sister. Santino said, A marker is not small thing John. What Santino means here is, the luxury house where John Wick lives and all of the things inside it are Santino's gift for him. Santino gave it all to John Wick because of that marker. John Wick replied, take it back. The fact is John Wick does not want to kill people again. Therefore, Santino warned John Wick that the marker is really important and it is the thing that a hit man should afraid of. Everybody who has bound by the marker must obey the rules. By saying that utterance, Santino warned John Wick that he still has an obligation to do his job as a hit man.

\subsection{THREAT}

Threat is an expression of an intention to inflict pain, injury, punishment or evil. It is a statement in which speaker tell someone that speaker will cause them harm or trouble if they do not do what speaker want. There are twelve utterances which categorized as threat found in the movie John Wick Chapter 2. The selected examples can be seen as follows:

Data 4

Abram's subordinate : So we're giving everything up for a car?

Abram : It's not just a car. It is John Wick's car.

Abram's subordinate $\quad:$ Oh 
(00:04:08-00:04:16)

The conversation is between Abram and his subordinate when they were on duty in Abram's headquarter. This conversation is about John Wick's car that currently among their inventories. John Wick's car was stolen by Losef Tarasov. When he stole John Wick's car, he also killed his dog. For that reason, Losef Tarasov and his father were killed by John Wick. Abram is Losef Tarasov's uncle who has crime business in New York City. Abram's utterance can be categorized as a threat since it is threatening to know that it is not just a car but it is John Wick's car. Abram used that statement to inform his subordinate to be aware because John Wick will come to inflict pain or injury to take his car back. He is a famous hit man also known as bogeyman, for that reason Abram says it's not just a car. It is John Wick's car. It's obvious that they will be in trouble.

Data 5

Santino D'Antonio: You came to me. I helped you. If you don't do this, you know the consequences.

(00:22:21 - 00:22:30)

This conversation is in John Wick's house where Santino visited John Wick to ask for a demand. It is Santino's right to ask John Wick due to the marker they have. If John Wick dishonoured the marker, it means he breaks the rules and he will get the punishments in underworld crime that governed by the High Table. When Santino threaten John Wick, he used imperative sentence. Santino told John Wick that if he did not fulfil the demand, he will get the consequences. The utterance can be categorized as threat since Santino gives an expression with an intention to inflict pain and punishment to John Wick. If John Wick did not do it, he will be in trouble. Santino wants John Wick to do what he wants and there is no reason to refuse it. He wants to make John Wick fulfilled his demand by reminding him the consequences he will get once he broke the rules and forgot about the marker.

Data 6

John Wick: I have no choice?

Winston: You dishonour the marker you die. You kill the holder of the marker you die. You run, you die.

(00:29:28-00:29:32)

The conversation is between Winston and John Wick in Continental Ground New York City. They talked about the consequences if John Wick broke the marker. Winston as John Wick's friend gave an advice to John Wick not to take a wrong decision. There is no way that John Wick can be free from the marker which finally force him back to be a hit man. Winston used imperative sentence to threaten John Wick. He wants to tell John Wick to avoid dangerous situation which put his life and family at risk. Winston utterance can be categorized into threat since it tries to threaten John Wick by describing the consequences of his decision if he dishonoured the marker. The only way he could free from the marker is by honouring the marker, following what the holder of the marker wants and completing his job.

\subsection{Promise}

Promise is an oral or written agreement to do or not to do something. It is an utterance used to remind the speaker about something to be done in the future. There are three utterances which categorized as promise found in the movie John Wick Chapter 2. The selected examples can be seen as follows:

Data 7

Aurelio : John, what thehell? I thought you love this car.

John Wick: What doyou think?

Aurelio : Your motor's a bout to fall out and, the chassis' all bent up, the... the driveshaft is all destroyed. And I don't know if you noticed, butyou got a crack in your windshield. I mean.... what do I th ink? I could fix it.

John Wick: Thanks forfinding her.

Aurelio : Not a problem, man. Just made a few calls. No big deal.

John Wick: Let me know when it's fixed.

Aurelio : All right. It will be ready Christmas. 
$(00: 17: 23-00: 17: 47)$

This conversation took place in John Wick's home between Aurelio and John Wick. They talked about the car of John Wick. Aurelio is John Wick's friend who own a garage and also works at underworld crimes in New York City. Aurelio came to John Wick's house to see the condition of John Wick's car and took it to his garage to repair it. Aurelio also helped John Wick to find his car which stolen by Abram's nephew.

Aurelio's utterance can be categorized into promise since he declared something to John Wick that he will do in the future. He gave assurance to John Wick to fix his car. He promised that the car will be ready on Christmas. When Aurelio saw John Wick's car for the first time, he was shock since it was badly broken, yet he knows John Wick really loves his car. Aurelio explained the problems of the car. When John Wick said, Let me know when it's fixed, he persuaded Aurelio to promise him. Then Aurelio replied, It will be ready Christmas, to show his commitment and the action that he will do in the future.

Data 8

Casian : I'll makeit quick. I promise.

John Wick: I appreciate that. I'll try and dothe same.

(01:07:29-01:07:38)

The conversation between John Wick and Casian took place in a bar at Rome Continental ground. At that moment, John Wick just finished his mission to kill Giana D'Antonio. Casian is also a hit man and the body guard of Giana D'Antonio and they have special relationship. He is so mad with John Wick and wants to revenge. Casian used declarative sentence since he declared something that he will do to John Wick in the future. It can be categorized as promise since Casian commits himself about something that he will do in the future. He promised to kill John Wick because John Wick kills Giana D 'Antonio. Casian says I'll make it quick. I promise. It means that he will kill John Wick as soon as possible. Afterwards John Wick replied, I appreciate that. I'll try and do the same, to show that he is not afraid of it.

\subsection{Refusal}

Refusal is the act of refusing, denial of anything demanded, solicited, or offered for acceptance. There are three utterances which categorized as refusal found in the movie John Wick Chapter 2. The selected examples can be seen as follows:

Data 9

Sa ntino D'Antonio: For a man to grant a marker to another, is to bind a soul to a blood oath.

John Wick : : Find someone else.

$(00: 21: 59-00: 22: 10)$

This conversation took place in John Wick's house when Santino came and asked him to kill his sister. They do not have any special relationship instead of business partner. John Wick refused Santino's demand by saying, Find someone else. It can be categorized as refusal since John Wick did not want to do Santino's demand. John Wick did not want to do that because he has retired. He retired because of his wife who has passed away. He did not want to be a hit man anymore since it made him having so many enemies and putting his wife and family in danger all the time.

Data 10

John Wick : I'm asking you don't do this

Sa ntino D'Antonio: I'm sorry. No one gets out and comes back without repercussion

(00:21:12-00:21:22)

The conversation is between Santino D'Antonio and John Wick. Santino kept forcing John Wick to kill his sister yet John Wick did not want to do it. He told Santino not to do this. However, Santino refused it by saying, No one gets out and comes back without repercussion. Santino's utterance can be categorized into refusal since Santino did not want to accept John Wick's suggestion. By saying that expression, Santino refused John Wick's suggestion and he wanted John Wick to accept his demand to kill his sister. It means that John Wick is not allowed to retire from being a hit man before he completed his job. 


\section{CONCLUSION}

This study analysed types of commissive speech acts in John Wick Chapter 2 movie and the meaning of its utterances. There are 25 data of commissive act found in John Wick Chapter 2 movie. The finding shows that there are four types of commisive speech acts, which predominantly used by the characters in the movie John Wick Chapter 2, they are: warning (48\%), threat (28\%), promise (12\%) and refusal $(12 \%)$. Warning is utterance that has purpose for other to be careful. Threat is an expression of an intention to inflict pain, injury, punishment, or evil. Promise is an utterance used to remind the speaker about something to be done in the future time. Refusal is an act of the speaker in refusing, denial of anything demanded, or offered for acceptance. Each character in this movie has different emotion when they deliver the utterances depend on the context of situation, the topic that being discuss, the participants, and language role. Among four types of commissive speech act, warning is the most dominant type which found in this movie. This type became more dominant than the others due to the genre of this movie, which is a thriller action movie. Thriller action movie is a blend of either action and thriller movie in which the protagonist confronts dangerous adversaries, obstacles, or situations that must be conquered. When the characters used commissive utterances, they determine what they will do in the future time. Through warnings, they make statements and tell people about possible danger, problem or any other unpleasant situation that might happen.

\section{REFERENCES}

Halliday, M.A K and Hasan, Ruqaiya. 1989. Language, Context and Text. Washington: Oxford University Press.

Mifflin, Houghton. 2003. Dictionary of the English Language. Retrieved from http://www.freedictionary.com, accessed on November 12th 2019.

Searle, John R. 1979. Expression and Meaning. Cambridge: Cambridge University Press.

Thomas, Jenny. 1995. Meaning in Interaction: An Introduction to Pragmatics. London: Lancaster University

Yule, George. 1996. Pragmatics (Oxford Introduction to Language Study). New York: Oxford University Press. 
